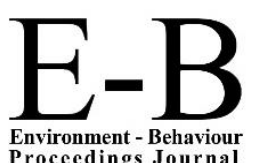

Environment - Behaviour

\title{
AIVCE-BS-2, 2020ShahAlam
}

https://www.amerabra.org; https://fspu.uitm.edu.my/cebs; https://www.emasemasresources.com/ AMEABRA International Virtual Conference on Environment-Bahaviour Studies, $2^{\text {nd }}$ Series cE-Bs, FSPU, Universiti Teknologi MARA, Shah Alam, 02-03 Dec 2020

\section{Knowledge and Practice on Breast Cancer among Female Community in Puncak Alam Campuses}

\author{
Roswati Nordin, Myzanuddin Hakim Hassri, Nur Farrah Nasuha Rozeman, Farah Wahidah Zulkifli \\ Centre for Nursing Studies, Faculty of Health Sciences, \\ Universiti Teknologi MARA, Puncak Alam Campus, 42300, Puncak Alam, Selangor, Malaysia.
}

roswati2809@uitm.edu.my, hakimmyzan@gmail.com, farrahnasueha88@gmail.com, fawa1503@gmail.com Tel: +60193725859

\begin{abstract}
In Malaysia, breast cancer is the primary cause of cancer-related death among women. It affected younger women correlates with poor survival and early detection can increase the quality of life. The study aims are to evaluate breast cancer awareness among the female community in UiTM Puncak Alam Campuses. A cross-sectional approach was used while conducting the study. It is found that the level of knowledge of breast cancer awareness relatively fair, and the level of practice is low. Hence, the proactive approach to instill the awareness on breast cancer must be strengthened by the expert in the field.
\end{abstract}

Keywords: Breast Cancer; Knowledge; Practice.

eISSN: 2398-4287@ 2020. The Authors. Published for AMER ABRA cE-Bs by e-International Publishing House, Ltd., UK. This is an open access article under the CC BYNC-ND license (http://creativecommons.org/licenses/by-nc-nd/4.0/). Peer-review under responsibility of AMER (Association of Malaysian Environment-Behaviour Researchers), ABRA (Association of Behavioural Researchers on Asians) and cE-Bs (Centre for Environment-Behaviour Studies), Faculty of Architecture, Planning \& Surveying, Universiti Teknologi MARA, Malaysia. DOI: https://doi.org/10.21834/ebpj.v5i15.2473.

\subsection{Introduction}

Breast cancer has a significant impact on females across the globe. The cancer develops from uncontrolled proliferation of malignant cells in the breast (Jordan et al., 2019). Awareness towards sign and symptoms of breast cancer remained low, which indicate that more studies are required to find out breast cancer awareness among the community (Katkuri \& Gorantla, 2018). Early detection increases the survival rate of patients as breast cancer is the most commonly occurring cancer among women globally, with $24.2 \%$ of the 8.6 million population, breast malignancy is the most ordinary diagnosed and the leading cause of cancer mortality, with $15 \%$ of the 4.2 million (Bray et al., 2018).

According to $\mathrm{WHO}$, to improve breast cancer outcomes and survival, early detection is significant (WHO, 2016). It seems that breast cancer among younger women is related to poor survival (Fredholm et al., 2017). Breast cancer can be detected through two strategies which are early diagnosis and screening. Screening can be done by undergoing mammogram procedures, breast self- examination (BSE), and clinical breast examination (CBE). Many experts suggest practicing Breast Self-Examination at the early age of 20. Based on the statistics, the mortality rate in Malaysia for 100,000 people with breast cancer has increased by 65.1 per cent annually since 1990, with an average of 2.8 per cent per year (Godfrey, K., Agatha, T., \& Nankumbi, J. 2016).

Malaysian women present breast cancer at an earlier age compared to women in Western countries (Yip et al., 2014). Awareness towards signs and symptoms of breast cancer in Malaysia remains low, and it is estimated that only 1 in 10 Malaysians women attend mammogram screening (Katkuri \& Gorantla, 2018). Early diagnosis and timely treatment are the primary factors of breast cancer survivors that provide an optimum chance of long-term survival of breast cancer patients, (Madubogwu, Egwuonwu, Madubogwu, \& Njelita, 2017).

eISSN: 2398-4287C 2020. The Authors. Published for AMER ABRA cE-Bs by e-International Publishing House, Ltd., UK. This is an open access article under the CC BYNC-ND license (http://creativecommons.org/licenses/by-nc-nd/4.0/). Peer-review under responsibility of AMER (Association of Malaysian Environment-Behaviour Researchers), ABRA (Association of Behavioural Researchers on Asians) and cE-Bs (Centre for Environment-Behaviour Studies), Faculty of Architecture, Planning \& Surveying, Universiti Teknologi MARA, Malaysia.

DOI: https://doi.org/10.21834/ebpj.v5i15.2473. 
A better prognosis of breast cancer is possible only if the disease is diagnosed at an early stage, therefore deeper understanding of the disease and self-assessment tend to be necessary. Nowadays, plenty of studies showed to identify the knowledge and practice of breast cancer awareness. However, there is a limited study conducted to determine the knowledge and practice of breast cancer awareness among female at the university community in Malaysia. Therefore, this study aims to evaluate breast cancer awareness, thus the objectives were to identify the level of knowledge and practice; correlate the socio-demographic with knowledge and practice among the female community in UiTM Puncak Alam Campuses.

\subsection{Literature Review}

The uninhibited production of malignant breast cells leads to breast cancer. This process may begin anywhere in the breast lobules, ducts, or stromal tissue and then give rise to different types of breast cancer (Jordan et al., 2019). Breast cancer is abnormal in cell growth and may arise as a result of mutations or alterations in genes that regulate cell division Breast. The American Cancer Society (ACS) described breast cancer occurs when the production of cells starts to get out of equilibrium. The uncontrolled cells can multiply and invade the surrounding tissues Breast malignancy is the most frequently diagnosed in women, and the second most prevalent cancer in the general population (Jordan et al., 2019).

Global numbers showed the yearly incidence of breast cancer is expanding, and this is taking place more rapidly in areas with a low incidence of breast cancer (Oladimej et al., 2015). Besides, $\operatorname{Ar}(2016)$ stated that the three most common cancers among Malaysian were breast $(24.4 \%)$, colorectal (15.4\%) and lung cancers (8.8\%). Female breast cancer was accounted for $32.1 \%$ of all cancer among females in Malaysia. The incidence of breast cancer was highest among Chinese, followed by Indian and Malay (Ar, 2016). Analysis between two academic hospitals in Malaysia and Singapore uncovered that almost half of the respondents were diagnosed before 50 years of age, closely related to research in foreign countries, such as the UK and the Netherlands (Fredholm et., al 2017). It is understood that there is insufficient knowledge of among youth, which could jeopardize early diagnosis and effective treatment (Yip et., al 2014).

Knowledge and practices on breast self-examination (BSE) are essential in every woman as it arises their level of awareness on early detection of that breast cancer (Madubogwu et al., 2017). According to the previous findings in 2015, 99.5\% of respondents knew about breast cancer, $69.1 \%$ of the respondents had learned about BSE, but just $38.9 \%$ of the respondents understood how to perform BSE (Nimir et., al 2014). This adequately addresses a lack of awareness on BSE practices among Malaysian youth, obstacles caused by insufficient health education for the target group. Also, a minimal number of respondents were conscious of the appropriate techniques for BSE palpation. This could be attributed to a weak community-based BSE education and the screening system among young female in Malaysia (Yip et., al 2014).

Other than that, according to a study by Oladimej et al., (2015), while respondents had a relatively good awareness of breast examinations, sparse level of clinical breast examination (CBE)h practice were found. Findings on a study by Modubogwu et al. (2017), noticed that the degree of awareness of mammography among respondents was substantial, at $90 \%$ knew that mammography was used as an early screening tool for breast cancer. $41.9 \%$ of respondents noted that mammography should be commenced from the age of 40 years and above while the rest responded inappropriately. Similarly, only $40.0 \%$ of the respondents knew that mammography should be done yearly. The level of education and occupation showed statistically significant correlation with the level of awareness of mammography. However, the level of practice of mammography was very poor; only $1.9 \%$ of the respondents have ever done mammography. Another report was showing that mammogram utilization was still lacking, about 7 to $30 \%$ of the study population (Mahmud \& Aljunid, 2018).

\subsection{Methodology}

\subsection{Population and Sampling Method}

The target population was the female community at Puncak Alam campuses. However, this study does not represent the whole female communities in UiTM Selangor Puncak Alam Campuses as it represents only two faculties which were FBM and FAC. The total number estimated was about 5205.

In this research, convenience sampling, which was a non-probability sampling method used to choose the respondents. The respondents were selected because of their convenient availability which it can save time. In this study, a questionnaire was distributed among the female community that was willing and available to answer the questionnaire. Krejcie and Morgan's formula were used to calculate the sample size of this study. The total sample obtained to proceed with this study was 357 .

\subsection{Instrument}

The research instrument used in this study was the questionnaire adapted and adopted from Madubogwu et., al (2017), entitled "Breast Cancer Screening Practices among Female Tertiary Health Worker in Nnewi". The questionnaire consists of 22 questions and were divided into three sections which were socio-demographic data, levels of knowledge and practice on breast cancer awareness.

\subsection{Data analysis}

The data obtained from the questionnaire answered by respondents were processed and analyzed using Statistical Package for the Social Sciences (SPSS) version 25.0 


\subsection{Findings}

\subsection{Socio-demographic Data}

The researchers grouped the age into two, which were, 19-22 years old and 23-26 years old. There were $236(66.1 \%)$ respondents from the age group of $19-22$ and $121(33.9 \%)$ from the age group of $23-26$.

There were only female communities from two faculties were participate in this study; the Faculty of Business Management (FBM) and the Faculty of Accountancy (FAC) UiTM Selangor, Puncak Alam Campus. The FBM participant who participated in this study consists of $200(56 \%)$ while FAC consists of $157(44 \%)$ of the participant.

\begin{tabular}{lc}
\multicolumn{2}{c}{ Table 1. Details on sociodemographic characteristic } \\
\hline Variable & $\mathrm{n}(\%)$ \\
\hline Age group & \\
$19-22$ & $236(66.1)$ \\
$23-26$ & $121(33.9)$ \\
\hline Faculty & \\
FBM & $200(56)$ \\
FAC & $157(44)$ \\
\hline
\end{tabular}

\subsection{Level of Knowledge on Breast Cancer Awareness}

The researchers found that almost all respondents were aware of breast cancer (99.4\%). However, only $80.4 \%$ of respondents ever heard of BSE. The level of knowledge was categorized into poor, fair and good knowledge level (Swe \& Bhardwaj, 2012). From the study, most of the respondents had a fair level of knowledge on breast cancer 213(59.7\%), and 113(31.7) had a good level of knowledge. Only $31(8.7 \%)$ of respondents had poor level knowledge regarding breast cancer.

Table 2. Level of knowledge on breast cancer awareness

\begin{tabular}{|c|c|c|c|}
\hline \multicolumn{4}{|c|}{ Level of Knowledge } \\
\hline Variable & $\begin{array}{l}\text { Poor } \\
(<33.3 \%)\end{array}$ & $\begin{array}{l}\text { Fair } \\
(33.3 \% \leq 66.6 \%)\end{array}$ & $\begin{array}{l}\text { Good } \\
(\geq 66.6 \%)\end{array}$ \\
\hline $\mathrm{n}(\%)$ & $31(8.7)$ & $213(59.7)$ & $113(31.7)$ \\
\hline
\end{tabular}

\subsection{Level of Practice on Breast Cancer Awareness}

The level of practice had been divided into three categories; poor $(<50 \%)$, fair $(50 \%-69 \%)$ and good $(>70 \%)$. It is showed that most of the respondents have a poor level of practice, with a total of $263(73.3 \%)$. On the other hand, 65 respondents practice it fairly. However, only 29 from a total of 357 respondents have a good level of practice.

Table 2. Level of practice on breast cancer awareness

\begin{tabular}{llll}
\hline \multicolumn{5}{c}{ Level of Practice } & \\
\hline Variable & $\begin{array}{l}\text { Poor } \\
(<50 \%)\end{array}$ & $\begin{array}{l}\text { Fair } \\
(50 \%-69 \%)\end{array}$ & $\begin{array}{l}\text { Good } \\
(>70 \%)\end{array}$ \\
& $263(73.3)$ & $65(18.2)$ & $29(8.1)$ \\
\hline $\mathrm{n}(\%)$ & & & \\
\hline
\end{tabular}

\subsection{The Relationship between Sociodemographic Data and Level of Knowledge on Breast Cancer Awareness}

Table 3. Association between sociodemographic data and the level of knowledge on breast cancer awareness

\begin{tabular}{|c|c|c|c|c|c|}
\hline \multicolumn{6}{|c|}{ Level of Knowledge } \\
\hline Variable & $\begin{array}{l}\text { Poor } \\
n(\%)\end{array}$ & $\begin{array}{l}\text { Fair } \\
n(\%)\end{array}$ & $\begin{array}{l}\text { Good } \\
n(\%)\end{array}$ & $\begin{array}{l}X 2 \\
\text { (df) }\end{array}$ & P-value \\
\hline $\begin{array}{l}\text { Age } \\
19-22 \\
23-26\end{array}$ & $\begin{array}{l}20(8.5) \\
11(9.1)\end{array}$ & $\begin{array}{l}143(60.6) \\
70(57.9)\end{array}$ & $\begin{array}{l}73(30.9) \\
40(33.1)\end{array}$ & $0.250(2)$ & 0.883 \\
\hline $\begin{array}{l}\text { Faculty } \\
\text { FBM } \\
\text { FAC }\end{array}$ & $\begin{array}{l}20(10.0) \\
11(7.0)\end{array}$ & $\begin{array}{l}130(65.0) \\
83(52.9)\end{array}$ & $\begin{array}{l}50(25.0) \\
63(40.1)\end{array}$ & $9.437(2)$ & 0.009 \\
\hline
\end{tabular}


Pearson's Chi-Squared Test was used to determine the relationship between the level of knowledge and sociodemographic data. It can be concluded that there is an extremely significant association between educational background and the level of knowledge on breast cancer awareness $(p=0.009)$.

\subsection{The Relationship between Sociodemographic Data and Level of Practice on Breast Cancer}

According to the results obtained, there is no significant association between age and the level of practice since the $p$-value exceeds the critical value $(p=0.107)$. The association of faculty and the practice has a $p$-value of $0.032(p<0.05)$. Hence, it can be concluded that the two variables are statistically significant.

Table 4. Association between sociodemographic data and the level of practice on breast cancer

\begin{tabular}{|c|c|c|c|c|c|}
\hline \multicolumn{6}{|c|}{ Level of Practice } \\
\hline Variable & $\begin{array}{l}\text { Poor } \\
\mathrm{n}(\%)\end{array}$ & $\begin{array}{l}\text { Fair } \\
\mathrm{n}(\%)\end{array}$ & $\begin{array}{l}\text { Good } \\
n(\%)\end{array}$ & $\begin{array}{l}X 2 \\
\text { (df) }\end{array}$ & P-value \\
\hline $\begin{array}{l}\text { Age } \\
19-22 \\
23-26\end{array}$ & $\begin{array}{l}178(75.4) \\
85(70.2)\end{array}$ & $\begin{array}{l}44(18.6) \\
21(17.4)\end{array}$ & $\begin{array}{l}14(5.9) \\
15(12.4)\end{array}$ & $4.479(2)$ & 0.107 \\
\hline $\begin{array}{l}\text { Faculty } \\
\text { FBM } \\
\text { FAC }\end{array}$ & $\begin{array}{l}158(79.0) \\
105(66.9)\end{array}$ & $\begin{array}{l}28(14.0) \\
37(23.6)\end{array}$ & $\begin{array}{l}14(7.0) \\
15(9.6)\end{array}$ & $6.882(2)$ & 0.032 \\
\hline
\end{tabular}

\subsection{Discussion}

\subsection{Levels of Knowledge and Practice on Breast Cancer}

Most of the respondent had fair knowledge due to easy access to gain information regarding breast cancer. The primary source of information was obtained from the media. Like other studies found that most of the respondent received information on BSE from media followed by books and hospital. Similar with other studies revealed that; most of the respondent had fair knowledge due to easy access to gain information regarding breast cancer and had achieved a limited level of knowledge regarding breast cancer (Dandash \& AlMohaimeed, 2007). Furthermore, almost all the respondents are aware of breast cancer however, only a few of respondents ever heard of BSE. There were most respondents agreed that a useful technique for early detection of breast cancer was BSE, but only a few of the respondents have been taught how to do BSE. Many respondents knew that BSE should be performed monthly, and most of the respondents had the idea of when BSE should be started. Majority of the respondents acknowledge that BSE performed by the individual. From the analysis, the researcher concluded that most of the respondents had a fair knowledge about breast cancer. Contrast with other studies by Alshahrani et al., (2019) also stated that approximately half of the respondents demonstrated a low level of breast cancer knowledge. On top of that, respondents may have an appropriate level of knowledge in breast cancer awareness, but the level of practice showed otherwise.

From the findings, reveals that most of the respondent had poor level of practices on breast cancer detection and breast selfexamination in the correct way. Similar with other results have demonstrated low practice of BSE which many of the respondents have poor practice on BSE (Birhane, 2017). Consistent with other findings, the most common barrier to practice BSE is the respondents might do not know to perform BSE using the correct way by Birhane et al., (2017). Like the findings by Parsa et al., (2011) reveals that the most common cause of abandoning BSE is due to lack of knowledge in performing BSE correctly. This study was focused more on BSE rather than CBE and mammography. These studies focused more on BSE because the targeted respondents were from the female university students age ranged from 19 to 25 years old. There were several studies show that BSE is one of an important way to detect cancer in young women, especially young women with an above-average risk of getting breast cancer such as their families to have a history of cancer disease.

\subsection{The Relationship between Sociodemographic Data with Level of Knowledge and Practice}

In respect to the result, age was not significantly associated with the knowledge of breast cancer. Similar findings by Dadzi \& Id (2019) found that there was no significant relationship between respondents' age and level of knowledge on breast cancer. Researchers concluded that due to the small age interval, level of knowledge between the two age groups was nearly equal, which showed no association between age and knowledge. However, a study conducted by Hassan, Ghazi, \& Mohamed, (2017), discovered that age was significantly associated with the level of knowledge on breast cancer which opposed to the present study. Moreover, from the results it is evidenced that faculties of the respondents were associates with the level knowledge on breast cancer especially on BSE since the respondents were from non-sciences backgrounds. This finding was consistent to research among South Asian women in Toronto (Chong et al., 2002). Additionally, a study performed by Hassan et al., (2017) to the undergraduate and postgraduate students demonstrated that the education status was related to the performance of BSE.

Researchers concluded that due to the small age interval, level of practices between the two age groups was nearly equal, which showed no association between age and practices. Similar findings were documented by a local study among students in Malaysia age 
from 18 to 22-year-old (Nimir et al., 2014). The results agree with a report from the previous research by Idowu (2019), which revealed that age was not significant to CBE awareness

In this study, it was ascertained that there were a significant association between the faculties and level of practices on BSE since the respondents involved in the studies from non-sciences backgrounds. The results were also in line with the previous research by Punjab et al., (2015). Besides, Al-dubai et al., (2012) stated that education levels correlate to the practices of BSE. In contrast, it was found that that age and educational status were not significant in BSE practices in studies by Erdem \& Tokta (2016) and Doganer et al., (2014).

\subsection{Conclusion \& Recommendations}

It is concluded that the female community at Puncak Alam campuses have high knowledge of breast cancer awareness, but the level of practice in terms of BSE is still low. Proactive actions must be done to create a female society that supports each other on breast cancer awareness to reduce the stigma that breast health is something to be ashamed of. Furthermore, a campaign for breast cancer awareness should be organized for free so that all female community at the campuses can be access to the knowledge of breast cancer awareness.

The campaign must emphasize on organizing a slot to demonstrate the correct technique to perform BSE. Next, posters about breast cancer and BSE should be placed in a busy area such as the hallway, cafés, and the lobby. Besides, the university or student's committee on the campus can put up infographics regarding breast cancer awareness into their official social media pages such as Instagram and Facebook. Besides, the university's corporate IT team can put up the digital infographic or even a reminder "Have you done your BSE today?" at all the digital advertisements boards.

Another way to raise breast cancer awareness is by setting the trend to wear a pink ribbon that indicates the wearer supports the breast cancer awareness campaign. However, it is crucial to emphasize by wearing a pink ribbon, meaning that they should know how to do BSE is one of the ways to support breast cancer awareness. It is essential to expose them at an early age of 20 years old minimum to create a habit to practice BSE regularly. Early detection is the key to prevent a contribution to breast cancer morbidity. Therefore, a further study needs to be identified the best method to guide the communities in performing BSE. However, to practice BSE requires proper knowledge of the technique used.

\section{Acknowledgements}

The author's wishes to thanks the Centre for Nursing Studies, Faculty Health Sciences, UiTM Puncak Alam and all the participants involved in the study.

\section{Paper Contribution to Related Field of Study}

This paper contributes to the health and wellbeing field of study.

\section{References}

Al-dubai, S. A. R., Ganasegeran, K., Alabsi, A. M., Rizal, M., Manaf, A., ljaz, S., \& Kassim, S. (2012). Exploration of Barriers to Breast-Self Examination among Urban Women in Shah Alam, Malaysia : A Cross Sectional Study. 13, 1627-1632.

Alshahrani, M., Alhammam, S. Y. M., Ali, H., Al, S., Mohammad, A., Alwadei, A., Mohammad, A., Alwadei, A., Saleh, S., \& Alzamanan, M. (2019). Knowledge, Attitudes, and Practices of Breast Cancer Screening Methods Among Female Patients in Primary Healthcare Centers in Najran , Saudi Arabia. 1167-1172.

Ar, M. O. H. P. I. K. N. (2016). Malaysian National Cancer Registry Report 2007-2011. National Cancer Institute, Ministry of Health Malaysia, 2016., 16. Retrieved from https://drive.google.com/file/d/OB59-Ld_mHScqTkhBaVNzOHNuQ0U/view

Birhane, K., Alemayehu, M., Anawte, B., Gebremariyam, G., Daniel, R., Addis, S., Worke, T., Mohammed, A., \& Negash, W. (2017). Practices of Breast Self-Examination and Associated Factors among Female Debre Berhan University Students. International Journal of Breast Cancer, 2017. https://doi.org/10.1155/2017/8026297

Bray, F., Ferlay, J., Soerjomataram, I., Siegel, R. L., Torre, L. A., \& Jemal, A. (2018). Global cancer statistics 2018: GLOBOCAN estimates of incidence and mortality worldwide for 36 cancers in 185 countries. CA: A Cancer Journal for Clinicians, 68(6), 394-424. https://doi.org/10.3322/caac.21492

Chong, P. N., Krishnan, M., Hong, C. Y., \& Swah, T. S. (2002). Knowledge and Practice of Breast Cancer Screening Amongst Public Health Nurses in Singapore. 43(10), 509-516.

Dadzi, R., \& Id, A. A. (2019). Assessment of knowledge and practice of breast self-examination among reproductive age women in Akatsi South district of Volta region of Ghana. 94, 1-12. https://doi.org/10.1371/journal.pone.0226925

Dandash, K. F., \& Al-Mohaimeed, A. (2007). Knowledge, attitudes, and practices surrounding breast cancer and screening in female teachers of buraidah, saudi arabia. International Journal of Health Sciences, 1(1), 61-71.

http://www.ncbi.nlm.nih.gov/pubmed/21475453\%0Ahttp://www.pubmedcentral.nih.gov/articlerender.fcgi?artid=PMC3068667 
Doganer, Y. C., Aydogan, U., Kilbas, Z., Rohrer, J. E., Usterme, N., Yuksel, S., ... Tufan, T. (2014). Predictors Affecting Breast Self-Examination Practice among Turkish Women, 15, 9021-9025

Erdem, Ö., \& Tokta, E. G. (2016). Knowledge, Attitudes, and Behaviors about Breast Self-Examination and Mammography among Female Primary Healthcare Workers in Diyarbak J r, Turkey. 2016.

Fredholm, H., Magnusson, K., Lindström, L. S., Tobin, N. P., Lindman, H., Bergh, J., Holmberg, L., Pontén, F., Frisell, J., \& Fredriksson, I. (2017). Breast cancer in young women and prognosis: How important are proliferation markers? European Journal of Cancer, 84, 278-289. https://doi.org/10.1016/j.ejca.2017.07.044

Godfrey, K., Agatha, T., \& Nankumbi, J. (2016). Breast cancer knowledge and breast self-examination practices among female university students in Kampala, Uganda: A descriptive study. Oman Medical Journal, 31(2), 129-134. https://doi.org/10.5001/omj.2016.25 https://doi.org/10.1016/j.ejca.2017.07.044

Hassan, M. R., Ghazi, H. F., Mohamed, A. S., \& Jasmin, S. J. (2017). Knowledge and practice of breast self-examination among female non-medical students in Universiti Kebangasaan Malaysia (UKM) in Bangi. Malaysian Journal of Public Health Medicine, 17(1), 51-58.

Idowu, A. (2019). Breast cancer awareness , knowledge and screening practice among women resident in an urban local government area of Oyo State, Nigeria. Journal of Cancer Policy, 20(August 2018), 100179. https://doi.org/10.1016/j.jcpo.2018.11.001

Jordan, V., Khan, M., \& Prill, D. (2019). Breast Cancer Screening: Why Can't Everyone Agree? Primary Care - Clinics in Office Practice, 46(1), 97-115. https://doi.org/10.1016/.pop.2018.10.010

Katkuri, S., \& Gorantla, M. (2018). Awareness about breast cancer among women aged 15 years and above in urban slums: a cross sectional study. International Journal of Community Medicine And Public Health, 5(3), 929. https://doi.org/10.18203/2394-6040.jicmph20180461

Madubogwu, C. I., Egwuonwu, A. O., Madubogwu, N. U., \& Njelita, I. A. (2017). Breast cancer screening practices amongst female tertiary health worker in Nnewi. Journal of Cancer Research and Therapeutics, 13(2), 268-275. https://doi.org/10.4103/0973-1482.188433

Mahmud, A., \& Aljunid, S. M. (2018). The uptake of mammogram screening in Malaysia and its associated factors: A systematic review. Medical Journal of Malaysia, 73(4), 202-211.

Nimir, A. R., Al-dubai, S. A. R., Alshagga, M. A., \& Saliem, A. M. (2014a). Knowledge and practice of breast self-examination among students in a private higher learning institution in malaysia ORIGINAL ARTICLE KNOWLEDGE AND PRACTICE OF BREAST SELF-EXAMINATION AMONG STUDENTS IN A PRIVATE HIGHER LEARNING INSTITUTION IN MALAYSIA. December.

Oladimeji, K. E., Tsoka-gwegweni, J. M., \& Igbodekwe, F. C. (2015). Knowledge and Beliefs of Breast Self- Examination and Breast Cancer among Market Women in Ibadan, South West,. 339, 1-11. https://doi.org/10.1371/journal.pone.0140904

Parsa, P., Kandiah, M., \& Parsa, N. (2011). Factors associated with breast self-examination among Malaysian women teachers. Eastern Mediterranean Health Journal, 17(06), 509-516. https://doi.org/10.26719/2011.17.6.509

Punjab, S., Noreen, M., Murad, S., Furqan, M., Sultan, A., \& Bloodsworth, P. (2015). Knowledge and Awareness about Breast Cancer and its Early Symptoms among Medical and Non-Medical Students of. 16.

World Health Organization. WHO Report on the Cancer statistics, (2016). Geneva: WHO

Yip, C. H., Pathy, N. B., \& Teo, S. H. (2014). <Yip 2014-A Review of Breast Cancer Research in Malaysia.pdf>. 69(August), 8-22 